Ukolova, Yu.I. (2020). Quantitative and qualitative aspects of the formation of traditional applied art of Mstera in the epoch of mass digitalization. Current Issues of Cultural Heritage in 2020. European Scientific e-Journal, 1 (1), 284290. Hlučín-Bobrovníky: “Anisiia Tomanek” OSVČ.

Уколова, Ю.И. (2020). Количественные и качественные аспекты формирования традиционного прикладного искусства Мстёры в эпоху массовой цифровизации. Current Issues of Cultural Heritage in 2020. European Scientific e-Journal, 1 (1), 284-290. Hlučín-Bobrovníky: “Anisiia Tomanek” OSVČ. (на ангх.)

DOI: $10.47451 /$ ped2020-09-001

The paper will be published in Crossref, ICI Copernicus, Academic Resource Index ResearchBib, J-Gate, ISI International Scientific Indexing, Zenodo, OpenAIRE, BASE, LORY, LUASA, ADL, eLibrary, and WebArchive databases.

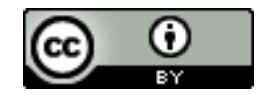

Yulia I. Ukolova, Director, F.A. Modorov Mstera Institute of Lacquer Miniature Painting, The branch of Higher School of Folk Arts (Academy). Mstera, Russia.

\title{
Quantitative and qualitative aspects of the formation of traditional applied art of Mstera in the epoch of mass digitalization
}

Abstract: With the advent of the 20th century and the arrival of new diverse artistic forms and trends, digital, network, and interactive art became an integral part of modern society. Digital art should be understood as an activity in the field of creativity based on the use of modern information technologies, where the product of activity is the latest types of copyrighted or modified works of art presented in a network environment using computer technologies. This article is devoted to modern trends and forms of perception of traditional applied art, in particular, the art of Mstera, which are associated with the general cultural and technical changes of modern times. The author analyzes the relevance of the concept of digitalization on the example of Mstera's lacquer miniature painting. The author concludes that the use of digital technologies in traditional ancient art is possible but only with a competent selection of methods to build work on the art work, where the applied will prevail over the "virtual".

Keywords: traditional applied art, Mstera lacquer miniature painting, professional art education, digital art, modern technologies, immateriality.

ЮАия Игоревна Укомова, Аиректор, Института маковой миниатюры им. Ф.А. Модорова, филиал Высшей школы народных искусств (Академии). Мстера, Россия.

\section{Количественные и качественные аспекты формирования традиционного прикладного искусства Мстеры в эпоху массовой цифровизации}

Аннотачия: С наступлением $\mathrm{XX}$ века и появлением новых разнообразных художественных форм и направлений цифровое, сетевое и интерактивное искусство стало неотъемлемой частью современного общества. Цифровое искусство слелует понимать как деятельность в области творчества, основанную на использовании современных информационных технологий, где продуктом деятельности явАяются новейшие виды защищенных авторским правом или модифицированных произведений искусства, представленных в сетевой среде с использованием компьютерных технологий. Аанная статья посвящена современным тенденциям и формам восприятия традиционного прикладного искусства, в частности, искусства Мстёры, которые связаны с общими культурными и техническими изменениями современности. Автор анализирует актуальность концепции цифровизации на примере маковой миниатюры Мстёры. Автор 
приходит к выводу, что использование цифровых технологий в традиционном Аревнем искусстве возможно, но только при грамотном выборе методов построения работы наА художественным произведением, где прикладное будет преобладать над «виртуальным».

Ключевъе слова: традиционное прикладное искусство, мстерская маковая миниатюра, профессиональное художественное образование, цифровое искусство, современные технологии, нематериальность.

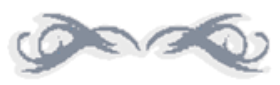

\section{Introduction}

With the advent of the 20th century and the arrival of new diverse artistic forms and trends, digital, network, and interactive art became an integral part of modern society (Denikin, 2017). Digital art should be understood as an activity in the field of creativity based on the use of modern information technologies, where the product of activity is the latest types of copyrighted or modified works of art presented in a network environment using computer technologies (Paul, 2003). Digital art can exist as telecommunications projects-installations, or be created by the author using computer specialized software. Already in the early 1980's, such art for contemporaries - critics, researchers and artists - represented the cutting edge between virtual reality and man. Digital technologies are now widely used around the world covering all aspects of human activity.

It would be correct to emphasize that with the development of globalization processes, digitalization in the field of art becomes an unavoidable component of the existence of culture involving the widespread introduction and use of innovations in the creative sector, including in the traditional applied arts of Russia. However, it becomes important to analyze and understand the quantity and quality of use and implementation of such modern technologies in ancient folk art. The introduction of the technological process should concern not only the sphere of culture in general but also adapt to the professional training of specialists in the field of traditional applied arts.

The phenomenon of the spread of digitalization as a means and causes of the globalization of society's culture creates a relationship between areas of various activities, the joint work of which was not possible previously.

The quantitative and qualitative aspects of the development of educational and artistic activities of this art in the era of mass digitization will be analysed on the example of one of the traditional applied arts - Mstera lacquer miniature painting.

In this case, the question is raised about the value of spiritual and material qualities of nondigital art, the prospect of a possible synthesis of traditional art and computer technology, due to modern trends in art in general. It is proved that digitalisation can only be an additional component of traditional applied art, representing its continuation in the latest conditions of existence.

For more detailed coverage of the issue, it is necessary to study the history of such types of art. One of these types of traditional applied art, in particular, in Russia, is the Mstera lacquer miniature painting. 
1.

Mstera is one of the centers of lacquer miniature painting, icon painting and artistic embroidery, which is located in the Vyaznikovsky district of the Vladimir region. New historical data on the time, when the settlement appeared on the bank of the Mstera river, the future Mstera Settlement, points to 1609 (Golyshev, 1865). From the beginning of the 18th century to the 1920s, icon painting, which later transformed into local lacquer miniature painting, developed in Mstera. The miniature of Mstera incorporated many features of iconography, in particular, Novgorod and Stroganov letters of the 17th century. At the same time, the convention of techniques became an organic and integral part of the art of Mstera, where every convention in folk art is based on the perception of the real and the experience of the past. Another source of artists' creativity is nature and modern reality transformed into the mainstream of the local art system.

Currently, the Mstera Institute of Lacquer Miniature Painting named after F. A. Modorov, the branch of the Higher School of Folk Arts (Academy) is the keeper of traditions and artistic and aesthetic values of perception of Mstera lacquer miniature art. The educational and scientific-educational activities of this branch are aimed at training highly qualified specialists in the field of icon painting, lacquer miniature painting and artistic embroidery. The Mstera Institute, represented by the teaching staff and employees of the branch, aims to form a stable interest in creative selfrealization and acquisition of skills in the miniature art of Russian folk craft when training future specialists in the field of Mstera lacquer miniature painting.

Modern trends set by the Mstera Institute in the field of miniatures are progressing and flourishing every year making new generations of artists. The base of the institute, which combines the preservation of traditions and innovative methods in teaching, is a unique experimental platform to test the idea of the synthesis of traditional art and modern digital technologies.

At the moment we can distinguish several traditional methods of mastering the knowledge of Mstera lacquer miniature painting:

1. Productive: reflection method, immersion method, etc. The main goal of the reflection method is to achieve development through the internal process of the student. Reflection promotes self-improvement of certain functions:

- communicative (effective interaction between teachers and students);

- semantic-creative (formation of students' ideas about the process of their own activities);

- motivational (gives the character of orientation of activity on the planned result, on effective cooperation of teachers and students);

- corrective (students' correction of their own activities, hanging the objectivity of their assessment and self-assessment).

The immersion method creates a comfortable, safe, artificial learning environment that is as close as possible to real conditions, immersing students in the atmosphere of artistic activity.

2. Reproductive: method of visibility, work with a book, etc. The essence of the method of visibility is that the teacher shows by example the ways to solve the problem, in this case, the construction of a compositional solution in a separate format, demonstration of samples, control of the process and quality of reproduction of the learned material by students. 
The ratio of 'traditional' and 'innovative' in applied art is one of the main problems considered in the theory of folk arts and crafts. In the modern realities of society, the question arises sharply what the driving force behind the development of art and its transition to new forms is. According to M.A. Nekrasova, a scientist in the field of folk art, folk traditions are not limited to an archaic form but dynamically develop with each new time period and generation. (Beshaposhnikova \& Zavaley, 2019) The system of traditional art itself is quite plastic. Based on these judgments, it becomes possible not to separate tradition and modernity but find new ways to develop the tradition. However, the stating element in the general concept of folk art, despite the modifications, must remain at a high spiritual, moral, and sensory-aesthetic level when creating works of traditional applied art.

A striking example of the acquisition of new forms of artistic traditions is the lacquer miniature painting of Mstera, where art is based on the fusion of ancient traditions and revolutionary technologies and techniques. Art and project activities of students studying Mstera lacquer miniature painting in the branch of the Higher School of Folk Arts is based on their educational and professional activities related to the processes of learning the educational environment through new forms.

"Modern audiences, especially young people, are focused on interactive and more personalized content, and this changes the way to perceive works of art and represent them," says $A$. Lavrov, an expert in virtual, augmented and mixed reality (VR/AR), President of $V R A R A$ Moscow Chapter (The Digitalization in the Field of Culture and Art, 2020).

\section{2.}

The origins of the modernization and transformation of traditional art into 'digital' should be found in the environment. Technological progress was consistently and incrementally changing the way of people thought about the world.

For modern people, it has become customary to organize the surrounding space into symbolic systems that is a rich field for the formation of new derivatives of traditional art forms. In this regard, the process of combining art with modern technologies becomes natural in general.

Digital information has become one of the objects of the new technological art. Modern art, created with the help of digital technologies, makes it possible for the viewer to interact with the work itself in real time introducing methods of interactive cognition. However, the question arises: Can traditional ancient art organically coexist with the mass digitalization of all activities?

One of these new forms is the digitalization of the educational process. The use of new digital technologies in creative disciplines and wide access to information and digital resources allowed to increase the number of hours of extracurricular work and a deeper study of the compositional and technological features inherent in the lacquer miniature painting of Mstera (Teplitskaya, 2020). This process of transition to the partial implementation of digital technologies in the curriculum was associated with the general concept of distance learning at the beginning of 2020, which was provoked by the holistic situation in the global education sector during the spread of viral infections.

However, such implementations in teaching the art of Mstera lacquer miniature painting are quite limited. This is due to the specific features of the tradition in the field of teaching folk art, 
formed over a centuries-old period. There are technical features of creating works of art that virtual reality cannot convey at the moment. This is the pressure of a pencil or brush, the consistency of paints, the density of the paint layer, etc., but as an additional auxiliary element in the study of traditional art, computer technology can quite organically coexist with traditional art.

Being in a small village, students have the opportunity to study works, stored in the collections, using the Internet to visit interactive exhibitions of world museums. Thanks to highquality digital technologies, detailed microscopic magnification of works of art becomes possible for an in-depth study of the techniques and techniques of writing by authors. Modern computer technology allows you to reduce the preparatory period preceding the work of a student of lacquer miniature painting directly on the material - an artistic blank made of papier-mache significantly facilitating the process to scale the author's compositional solutions in any format. Digital image editors allow you to modify projects of art works in the style of Mstera lacquer miniature painting to meet the necessary criteria for compositional solutions.

Modern digital technologies are closely intertwined in the process of creating of traditional applied art artistic works including the Mstera lacquer miniature painting. However, it is necessary to separate the qualitative aspects from quantitative ones of mass digitalization in art and the ways of affect the methods and mastering the knowledge of future artists.

Methods of knowledge acquisition are determined by the tasks, object and subject of study. The collection of new facts and their interpretation within the chosen task can determine the constructiveness of the model underlying the entire process of knowledge acquisition.

It is necessary to identify key terms to understand aspects of digitalisation in the framework to teach Mstera lacquer miniature painting. Under the qualitative or quantitative aspects of the formation of Mstera traditional applied art, we may understand general concepts and criteria related to the definition of a particular art form, which are based on certain characteristic features.

It is not possible to evaluate all the results of the development of activities in quantitative objective units. Most of the characteristics of evaluating art and the results of creating art works are not strictly quantifiable. For their evaluation, it is more appropriate to use qualitative indicators, measured using expert assessments, which in turn are a subjective indicator that has a large number of variables. However, quality indicators in art are ahead of time and influence the final result of creating an artistic work. Control of quality indicators by the expert commission entails improvement of quantitative indicators being a logical chain of "cause and effect".

The qualitative aspects of the art of Mstera lacquer miniature painting should include the traditions of execution, technique, writing techniques, compositional solution, author's idea, color scheme, ornamental framing of the painting field, selection of the shape of the art blank from papier-mache and much more. To meet these criteria, as an auxiliary element, it is possible to use information technologies but only at the preparatory stage.

In electronic format, quantitative aspects of digital learning of Mstera lacquer miniature painting allow to accelerate the preparatory process itself, but it is worth emphasizing that when the threshold of speed criteria increases, in most cases, the quality begins to decrease prevailing over the quantity. The traditional applied art of Mstera is unique. The works are created by the 
authors in a single copy with natural artistic materials on a natural ecological billet. The acceleration of the rate of works' creation leads to a decrease in the quality of the work itself transferring it from the rank of a highly artistic work to a souvenir of printed production.

\section{Conclusion}

When discussing methods of data collecting and interpreting to analyse any art, the contrast of quantitative and qualitative approaches to the study of the problem is traditional dividing the assessment into standardised and expert methods. The assessment of any of the above categories is based on the characteristics of properties, but in the case of studying the question of art including traditional applied art, it is impossible to assess the correctness to use certain techniques in terms of strictly formulated rules. In relation to lacquer miniatures, there is a greater degree of expert assessment based on the professional experience and intuition of a specialist who has proven himself in this field of art. Thus, the study of the impact and implementation of digital technologies in teaching traditional applied arts is rather a sub-scientific method of judgment without falling into the category of objective.

In accordance with the quantitative and qualitative aspects of digitalization of Mstera lacquer miniature painting and traditional applied art in general, in the frame of the research, it is possible to talk about social knowledge of the application of methods to train future artists and subjectivity factors that carry a non-standard character. Totally, the use of digital technologies in traditional ancient art is possible but only with a competent selection of methods to build work on the art work, where the applied will prevail over the "virtual".

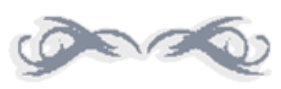

\section{References:}

Beshaposhnikova, Y.A., \& Zavaley, D.V. (2019). Implementation of M.A. Nekrasova's concept of merging tradition and modernity in the art of lacquer miniature painting in the practice of teaching students of the Higher School of Folk Arts. Traditional Applied Arts and Education, 3, 129-145. (in Russian)

Denikin, A.A. (2017). Post-digital aesthetics in digital art practices. The Space of Art and Cultural Life. The Observatory of Culture, 1 (14), 36-45. (in Russian)

Golyshev, I.A. (1865). Bogoyavlenskaya Sloboda Mstera: History of antiquity, statistics and Ethnography. Proceedings of the Vladimir Provincial Statistical Committee, 4. Vladimir. (in Russian) Paul, C. (2003). Digital Art. London: Thames \& Hudson.

Teplitskaya, A.A. (2020). Traditional and innovative educational technologies in the professional formation of the artist of traditional applied art. Traditional Applied Arts and Education, 1, 20 29. (in Russian)

The Digitalization in the Field of Culture and Art (March 19, 2020). Tadviser. Retrieved March 15, 2020, from https://www.tadviser.ru/a/513057 (in Russian) 